\title{
Peningkatan Kualitas dan Kuantitas Air Bersih di Masjid Al-Hijrah Karang Joang Kota Balikpapan
}

\author{
Tatag Yufitra Rus*, Ali Arifin Soeparlan, Masrul Huda, Ezra Hartarto Pongtuluran \\ Politeknik Negeri Balikpapan, Indonesia \\ Email: tatag.yufitra@poltekba.ac.id
}

\begin{abstract}
ABSTRAK
Kebutuhan akan air baku adalah hal yang paling mendasar dalam kehidupan sehari- hari terutama dalam kebutuhan tempat ibadah di Masjid Al-Hijrah Km. 8 Kelurahan Karang Joang Kecamatan Balikpapan Utara. Sumber air utama di Masjid tersebut masih mengandalkan sumur bor dikarenakan belum terinstalasinya jalur pipa induk PDAM di wilayah tersebut. Namun, kualitas air baku di Masjid tersebut masih tidak layak untuk digunakan berwudhu dan bersuci dikarenakan kadar kekeruhan, keasaman, dan zat besi yang tinggi melampaui kadar yang diijinkan sesuai standar Permenkes. Pembangunan WTP di Masjid tersebut sangat bermanfaat sebagai peningkatan kualitas dan kuantitas air bersih. Dimensi dari bangunan WTP ialah $200 \times 300 \mathrm{~cm}$ dengan tinggi $100 \mathrm{~cm}$, sehingga bangunan WTP tersebut mampu menampung air bersih sekitar $5 \mathrm{~m}^{3}$. Sebagai penyaring dasar dari sumur air bor, bangunan WTP dilengkapi dengan material pengisi filter berupa batu pecah, arang, geotextile, dan pasir. Tahapan kegiatan dimulai dengan perencanaan desain bangunan dan sistem filter WTP, pelaksanaan pekerjaan bangunan WTP, dan pengisian filter air. Pekerjaan bangunan WTP ini diselesaikan dengan durasi \pm 30 hari.
\end{abstract}

Kata Kunci: Air Bersih, Masjid Al-Hijrah, WTP, Filter.

\section{PENDAHULUAN}

Kebutuhan akan air baku adalah hal yang paling mendasar dalam kehidupan sehari- hari terutama dalam kebutuhan tempat ibadah di Masjid Al-Hijrah Km. 8 Kelurahan Karang Joang Kecamatan Balikpapan Utara. Air baku bersih yang mampu didistribusikan secara maksimal hanya sekitar 90\% (Widya, 2018) melalui PDAM Kota Balikpapan. Masjid Al-Hijrah sejak 30 Tahun terakhir belum pernah menerima pasokan air baku bersih melalui jalur pipa induk PDAM Kota Balikpapan. Sehingga dalam pemenuhan kebutuhan air bersih di Masjid tersebut, warga hanya mengandalkan air hujan atau mengambil air di sumur tua yang berjarak kurang lebih $500 \mathrm{~m}$ dari lokasi Masjid. Hanya sejak 3 tahun terakhir ini Masjid tersebut dapat memenuhi kebutuhan air secara mandiri melalui pemasangan sumur bor tanah. 


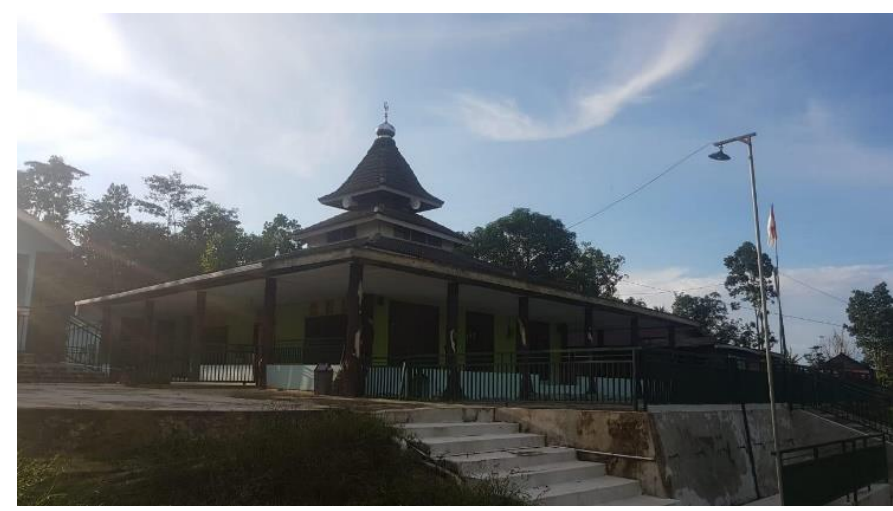

Gambar 1. Masjid Al-Hijrah di Jl. Kesatriaan Km. 8 Kota Balikpapan

Permasalahan yang timbul saat ini adalah kualitas dan kuantitas air baku dari sumur bor tanah di Masjid Al-Hijrah. Dimana terdata bahwa, dengan jumlah debit yang dapat diperoleh dari penggunaan sumur hanya sekitar $2.4 \mathrm{~m}^{3} /$ hari atau 6 liter/menit, maka perlu ada peningkatan tampungan yang harus ditambah untuk kebutuhan sehari- hari. Kualitas air di tersebut juga sangat mengkhawatirkan dengan kondisi air keruh dan berbau zat besi melebihi kadar maksimal diizinkan untuk digunakan terhadap kulit langsung. Maka perlu ada penanganan dalam peningkatan kualitas dan kuantitas kebutuhan air tersebut melalui Program Pengabdian Kepada Masyarakat dengan judul "Peningkatan Kualitas dan Kuantitas Air Bersih di Masjid Al-Hijrah Kelurahan Karang Joang Kota Balikpapan”.

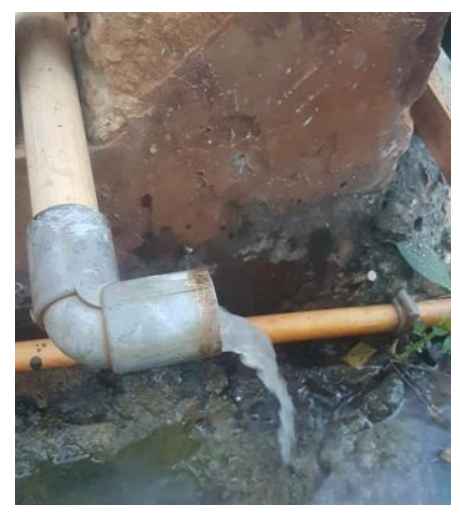

Gambar 2. Kondisi Air di Masjid Al-Hijrah melalui Pengamatan Visual

Dalam penerapannya, untuk meningkatkan kualitas dan kuantitas air bersih di Masjid Al- Hijrah, diperlukan pembangunan Water Treatment Plant WTP yang nantinya bukan hanya sebagai tambahan tampungan air untuk meningkatkan kuantitas air bersih dari sumur bor tanah melainkan juga dapat meningkatkan kualitas air melalui proses penyaringan dan pengendapan air asal untuk didistribusikan ke Masjid tersebut untuk penggunaan sehari-hari dalam keperluan ibadah.

\section{METODE PELAKSANAAN}

\section{Peninjauan Kondisi Kualitas Air Baku}

Peninjuan kondisi kualitas air baku yang dimiliki Masjid Al-Hijrah berguna untuk penentuan desain pada sistem penyaringan WTP yang dibutuhkan untuk peningkatan kualitas air baku 
tersebut. Kualitas air bersih tersebut dilakukan di UPTD Laboratorium Kesehatan Daerah Kota Balikpapan dengan mengacu pada standar Permenkes RI: NO .32/MENKES/2017.

Berdasarkan pada Tabel 1, didapatkan bahwa secara fisik air tersebut kurang layak digunakan untuk keperluan sehari-hari Masjid seperti wudhu dan bersuci. Dikarenakan kadar kekeruhannya sangat tinggi yaitu nilai kekeruhan sebesar 936 dari batas yang diperbolehkan yaitu 25 oleh Permenkes. Secara kimia juga nilai kadar besi sebesar 6,42 dan keasaman 5,37 diluar dari batas yang diperbolehkan tentang standar baku mutu kesehatan lingkungan untuk keperluan sanitasi yang higienes yaitu untuk Ph yang diijinkan hanya sebesar 6,5-8,5 dan zat besi hanya sebesar 1. Sehingga memang perlu dilakukan pembangunan WTP yang mana sebagai penyaringan dasar air sumur sebelum dilakukan pengendapan dan filterisasi di bak penyimpanan air.

Tabel 1. Laporan Hasil Uji Lab Kualitas Air Baku (Sumber: UPTD Laboratorium Kesehatan Daerah Kota Balikpapan)

\begin{tabular}{llcc}
\hline No & Parameter & $\begin{array}{c}\text { Kadar } \\
\text { Maksimum } \\
\text { Diijinkan }\end{array}$ & $\begin{array}{c}\text { Hasil } \\
\text { Pemeriksaan }\end{array}$ \\
\hline 1 & Kekeruhan & 25 & 936 \\
2 & Warna & 50 & 224,2 \\
3 & Ph & $6,5-8,5$ & 5,37 \\
4 & Besi & 1 & 6,42 \\
\hline
\end{tabular}

\section{Perencanaan Desain WTP}

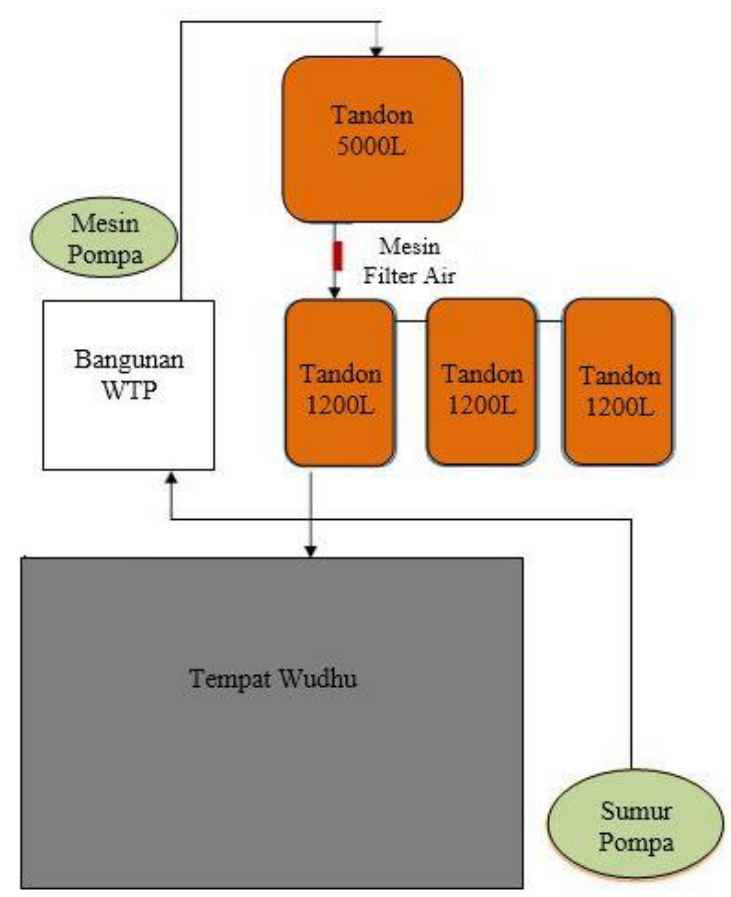

Gambar 3. Desain Sistem Aliran Air dari WTP 
Perencanaan desain WTP bertujuan untuk peningkatan kualitas standar air bersih sesuai standar Permenkes dengan membangun sistem bangunan WTP berukuran $200 \mathrm{~cm}$ x $300 \mathrm{~cm}$ dengan tinggi $100 \mathrm{~cm}$ menggunakan sistem penyaringan lambat seperti terlihat pada Gambar 5. Bangunan WTP tersebut berdiri diatas pondasi cakar ayam yang dibangun 4 titik di setiap sudut bangunan.

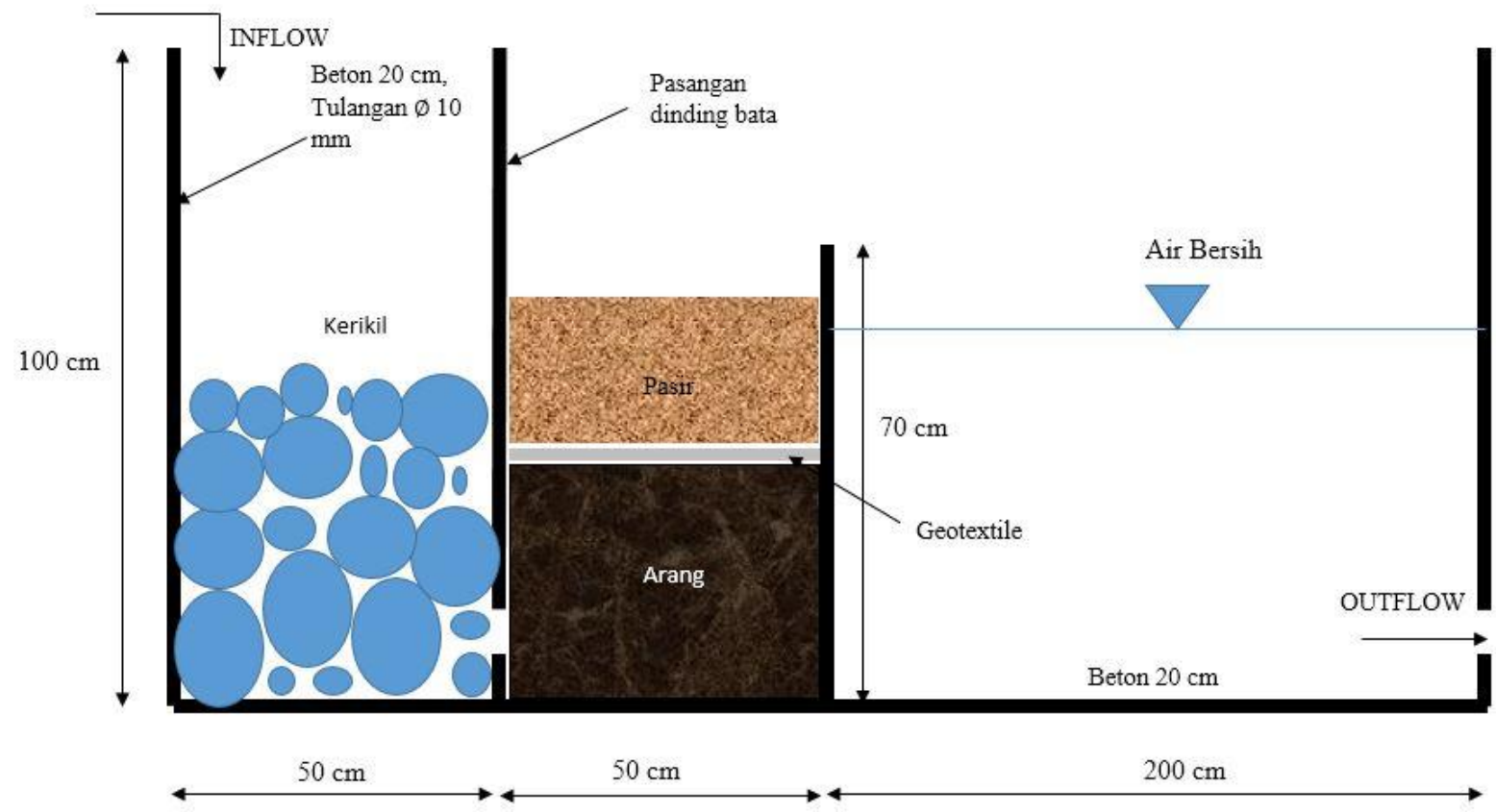

Gambar 4. Desain Potongan Bangunan WTP di Masjid Alh Hijrah

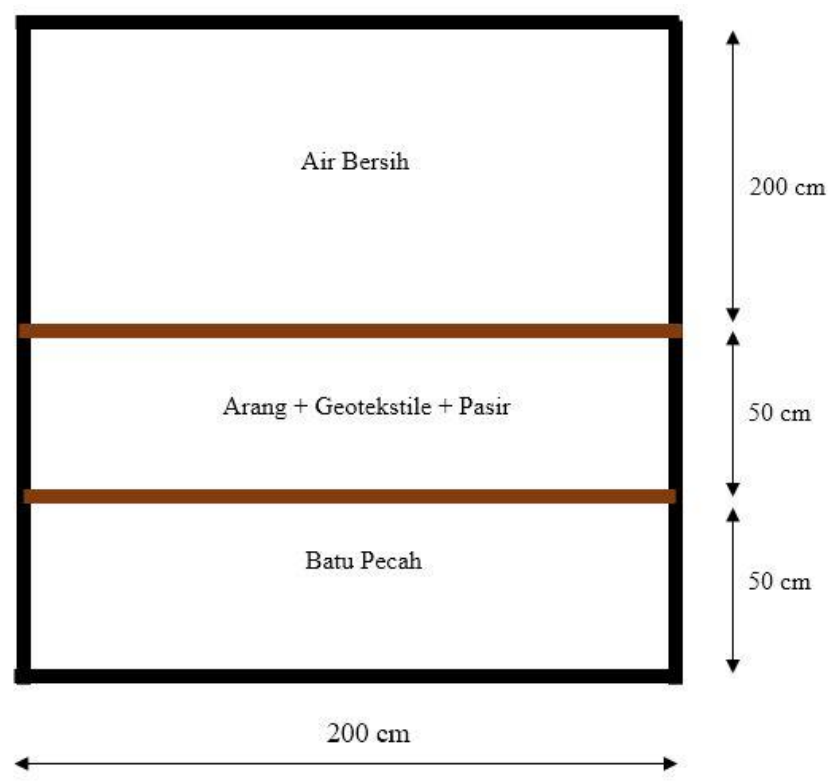

Gambar 5. Tampak Atas Desain WTP 
Manfaat dari WTP ini dapat digunakan bukan hanya sebagai menambah tampungan atau kauntitas air bersih yang sudah ada, namun juga dapat meningkatkan kualitas air bersih di Masjid Al-Hijrah tersebut dikarenakan air yang akan difiltrasi dengan mesin filtrasi sudah melalui proses pengendapan dan penyaringan melalui saringan pasir, arang, dan batu pecah seperti terlihat pada Gambar 4. Dengan desain sebesar $200 \mathrm{~cm}$ x $300 \mathrm{~cm}$ nantinya kuantitas penyimpanan air bersih juga bertambah $\pm 5 \mathrm{~m}^{3}$. Hal ini sangat membantu kebutuhan Masjid Al-Hijrah dikarenakan sumber air yang digunakan hanya mengandalkan sumur bor saja.

Penerapan sistem WTP dengan sistem pengendapan dan penyaringan lambat sebelum menggunakan mesin filter air, sehingga kondisi air bersih di Al-Hijrah tersebut dapat dimaksimalkan dari sebelumnya dengan mengadopsi teknologi tersebut seperti yang terlihat pada Gambar 4. Program ini juga nantinya dapat berguna sebagai pemberdayaan kegotongroyongan antar warga di sekitar lokasi tersebut dengan terlibatnya warga sekitar dalam proses perencanaan, pelaksanaan, pengawasan, dan perawatan konstruksi sistem air bersih kedepan.

\section{HASIL DAN PEMBAHASAN}

\section{Kegiatan Pekerjaan Bangunan WTP}

Dalam pelaksanaannya, kegiatan pembangunan WTP ini membutuhkan durasi waktu sekitar 7 hari seperti terlihat pada Tabel 2.

Tabel 2. Urutan Kegiatan dan Durasi Waktu Pelaksanaan Pekerjaan Bangunan WTP

\begin{tabular}{|l|l|l|l|l|l|l|l|}
\hline \multirow{2}{*}{ Kegiatan } & \multicolumn{7}{c|}{ Hari } \\
\cline { 3 - 9 } & 1 & 2 & 3 & 4 & 5 & 6 & 7 \\
\hline Pekerjaan pondasi cakar ayam & & & & & & & \\
\hline Pekerjaan pelat dasar WTP & & & & & & & \\
\hline Pekerjaan kolom & & & & & & & \\
\hline Pekerjaan pasangan dinding & & & & & & & \\
\hline Pekerjaan plester & & & & & & & \\
\hline Pekerjaan acian & & & & & & & \\
\hline Pekerjaan cat waterprof & & & & & & & \\
\hline
\end{tabular}

Pada pekerjaan pondasi cakar ayam, dimensi yang digunakan ialah 50 × 50 × $30 \mathrm{~cm}$. Jumlah pondasi cakar ayam sebanyak 4 titik, dimana pondasi cakar ayam tersebut dibangun di setiap sudut bangunan WTP. Tulangan yang digunakan ialah tulangan polos dengan $\emptyset 10$ mm. Pekerjaan pelaksanaan pondasi cakar ayam ini dimulai dengan pembersihan dan penggalian titik pondasi cakar ayam, perakitan tulangan, dan pengecoran beton kedalam lubang galian.

Pekerjaan pelat dasar bangunan WTP dilaksanakan setelah beton pada pondasi cakar ayam mengeras. Pada pekerjaan pelat dasar bangunan WTP menggunaan besi tulangan polos $\varnothing 10 \mathrm{~mm}$ dengan tebal beton sekitar $20 \mathrm{~cm}$ untuk menopang air pada bangunan WTP seluas $200 \times 300 \mathrm{~cm}$. Pekerjaan pelat dasar bangunan WTP ini dimulai dengan perakitan tulangan, pemasangan bekisting, dan pengecoran beton.

Pekerjaan selanjutnya ialah pekerjaan kolom sebagai pengikat pasangan dinding untuk kekuatan utama bangunan WTP menahan tekanan air. Dimensi kolom yang didesain ialah 15 x $15 \mathrm{~cm}$ dengan tinggi $100 \mathrm{~cm}$. Tulangan yang digunakan ialah dengan tulangan polos $\emptyset 10 \mathrm{~mm}$. Pekerjaan kolom ini dilaksanakan dengan perakitan tulangan, pekerjaan bekisting, dan pengecoran kolom. 
Setelah pekerjaan seluruh struktur bangunan WTP selesai. Selanjutnya pekerjaan dapat dilakukan dengan pemasangan dinding, pekerjaan plesteran, pekerjaan acian, dan pengecatan waterprof. Pekerjaan dinding menggunakan bata merah dengan tinggi $1 \mathrm{~m}$. Selanjutnya pada pekerjaan plesteran yang digunakan ialah dengan campuran mortar 1:2. Setelah pekerjaan plesteran selesai, maka dilanjutkan dengan pekerjaan acian dan diakhiri dengan pengecatan waterprof dengan tujuan agar bangunan WTP dipastikan mampu menahan dari rembesan karena seluruh pori-pori bangunan WTP telah tertutup.

\section{Perakitan Sistem Filter pada Bangunan}

Pada pekerjaan ssistem filter ini, bangunan WTP telah didesain menggunakan sistem filter dari kombinasi antara batu pecah, arang, geotekxtile, dan pasir. Penggunaan batu pecah diharapkan mampu melarutkan kadar lumpur yang terbawa saat air dari sumur bor masuk pertama kali ke dalam bangunan WTP. Dengan mengandalkan tekanan air, air yang masuk kedalam filter batu pecah tersebut akan mengalir ke filter arang dengan fungsi sebagai karbon aktif untuk menjernihkan air dan menyaring zat besi untuk menurunkan kadar besi yang terkandung pada air dari sumur bor tersebut. Selanjutnya pemisah material antara pasir dan arang menggunakan geotextile dengan tipe non woven yang juga mampu sebagai filter air. Pada tahap terakhir, air akan mengalir ke dalam filter pasir yang berguna sebagai penjernihan air dan material pasir yang digunakan ialah pasir palu. Pemilihan pasir palu ini dianggap paling baik dikarenakan pasir tersebut dengan diameter dan gradasi ukuran butirnya sangat baik sebagai filter air.

\section{KESIMPULAN}

Kesimpulan dari pelaksanaan pengabdian pada masyarakat ini ialah telah diselesaikannya bangunan WTP pada Masjid Al-Hijrah dengan tujuan untuk peningkatan baik dari segi kualitas dan kuantitas pada air baku yang berasal dari sumur bor untuk digunakan jamaah Masjid untuk berwudhu dan bersuci. Poin-poin pada kesimpulan kali ini ialah:

1. Berdasarkan hasil uji Laboratorium pada sample air sumur bor di Masjid Al-Hijrah, ditemukan bahwa air tersebut memiliki kualitas yang tidak layak digunakan untuk kebutuhan sehari-hari jamaah masjid dikarenakan memiliki kadar kekeruhan, zat besi, dan keasaman yang tinggi ditinjau pada standar Permenkes.

2. Pelaksanaan pekerjaan WTP di Masjid Al-Hijrah dimulai dengan tahap perencanaan desain bangunan WTP dan jalur pipa air, pekerjaan bangunan WTP, dan pengisian material filter air pada bangunan WTP.

3. Pelaksanaan pekerjaan total memakan waktu sekitar 30 hari sejak perencanaan bangunan WTP hingga pengisian material filter air diselesaikan.

\section{UCAPAN TERIMA KASIH}

Ucapan terima kasih kami sampaikan kepada seluruh warga lingkungan Masjid Al-Hijrah yang membantu proses terselesaikannya pelaksanaan pembangunan WTP di Masjid AlHijrah. Terima kasih sebesar-besarnya juga kami haturkan kepada Jurusan Teknik Sipil yang mendukung kegiatan pembangunan WTP tersebut dalam pelaksanaan program Pengabdian Kepada Masyarakat. 


\section{DAFTAR PUSTAKA}

Alwin, M. (2017). Penggunaan Bahan Alam Zeolit, Pasir Silika, dan Arang Aktif dengan Kombinasi Teknik Shower dalam Filterisasi Fe, Mn, dan Mg pada air tanah di UPN “Veteran” Yogyakarta. Seminar Nasional Kebumian Ke- 10, (pp. 1127-1137 ). Universitas Gajah Mada, Yogyakarta.

Kelompok Teknologi Pengelolaan Air Bersih dan Limbah Cair, Direktorat Teknologi Lingkungan, Badan Pengkajian dan Penerapan Teknologi. (2018). Teknologi Pengolahan Air Bersih dengan Proses Saringan Pasir Lambat "Up Flow”. Artikel. Jakarta.

Widya, W. (2018). Kebutuhan Air Bersih Kota Balikpapan Tahun 2018. Jurnal Ilmiah Keselamatan dan Lindungan Lingkungan (IDENTIFIKASI). Universitas Balikpapan, Balikpapan. 